\title{
ANALISIS KALOR DAN SINTESIS BIOETANOL DARI SERABUT KELAPA SAWIT SEBAGAI ALTERNATIF BAHAN BAKAR TERBARUKAN
}

\section{Analysis of Heat and Synthesis of Bioethanol from Palm Fibers as an Alternative Renewable Fuels}

\author{
*Arsyad, Anang W. M. Diah, dan Irwan Said \\ Pendidikan Kimia/FKIP - Universitas Tadulako, Palu - Indonesia 94118 \\ Received 16 September 2015, Revised 16 October 2015, Accepted 16 November 2015
}

\begin{abstract}
Palm fibers are solid waste from the palm oil processing plant. Palm fibers can be used as an alternative fuels for traditional and modern (bioethanol). This study aims to determine the amount of heat generated from the burning of palm fibers, and determine the number of conversions of bioethanol from palm fibers through the fermentation techniques. In this study used a bomb calorimeter is determine heat value and apply through fermentation using saccharomyces cereviseae in various times of 5 and 11 days to synthesis ethanol. The step in this study were sample preparation, delignification, hydrolysis with acid variation, and fermentation. Determination of bioethanol content from the fermentation was analysed using ethanol sensor. The heat value of palm fibers is equal to 4708.21 callg and the highest ethanol fermented product obtained on days 11, ie 5.23\%. It can be concluded that palm fibers can be used potentially as an alternative renewable fuels to substitute coal or diesel power.
\end{abstract}

Keywords: Heat analysis, bioethanol, palm fibers.

\section{Pendahuluan}

Krisis energi dunia merupakan masalah yang sedang dihadapi oleh banyak negara termasuk Indonesia. Krisis ini terjadi akibat ketergantungan pemenuhan energi bahan bakar dunia yang berasal dari bahan bakar fosil. Padahal bahan bakar ini merupakan sumber daya alam yang yang tidak dapat diperbaharui dan ketersediannya didunia sangat terbatas (Haryono, dkk., 2010)

Pabrik kelapa sawit berkapasitas 60 ton tandan/jam dapat menghasilkan 100 ton limbah padat (Akhmad, dkk., 2012). Di Indonesia, terdapat 470 pabrik pengolahan kelapa sawit. Limbahnya mencapai 28,7 juta ton dalam bentuk cairan dan 15,2 juta ton limbah padat per tahun. Padahal limbah sawit kaya akan selulosa dan hemiselulosa yang dapat diolah menjadi etanol. Tandan kosong kelapa sawit masing-masing mengandung $45 \%$ selulosa dan $26 \%$ hemiselulosa. Tingginya kadar selulosa

\section{*Correspondence:}

Arsyad

Program Studi Pendidikan Kimia, Fakultas Keguruan dan

Ilmu Pendidikan, Universitas Tadulako

email: uzumakiarsyad@gmail.com

Published by Universitas Tadulako 2015 pada polisakarida tersebut dapat dihidrolisis menjadi gula sederhana dan selanjutnya difermentasi menjadi etanol (Akhmad, dkk., 2012). Bioetanol dapat diproduksi dengan langkah-langkah antara lain delignifikasi, hidrolisis, fermentasi, dan pemisahan. (Jannah, 2010). Delignifikasi dipengaruhi oleh beberapa faktor antara lain: waktu pemasakan, konsentrasi larutan pemasak, pencampuran bahan, perbandingan larutan pemasak dengan bahan baku, ukuran bahan, suhu dan tekanan (Sumada, dkk., 2011). Metode pretreatment yang berbeda untuk bahan lignoselulosa telah dijelaskan dan dipelajari secara luas untuk meningkatkan produksi etanol. Semua metode ini harus membuat lignoselulosa dapat diakses reaksi enzimatik, di mana kristalinitas selulosa yang dapat diperkecil, serta pembuangan lignin dan hemiselulosa adalah faktor utama yang mempengaruhi hidrolisis enzimatik. Di antara metode yang berbeda yaitu kimia dan termokimia, saat ini yang paling efektif dan termasuk yang paling menjanjikan adalah teknologi untuk aplikasi industry (Alvira, dkk., 2009). 


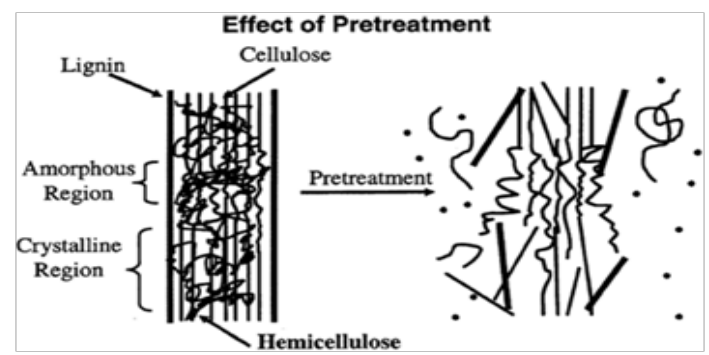

Gambar 1. Fungsi pretreatment (Balat, 2011).

Bioetanol adalah bahan bakar oksigen yang mengandung $35 \%$ oksigen, yang mengurangipartikulat danemisi NOx dari pembakaran. Etanol memiliki angka oktan yang lebih tinggi (108), mudah terbakar dan kecepatan nyala lebih tinggi. Sifat ini memungkinkan untuk rasio kompresi yang lebih tinggi dan waktu membakar yang lebih pendek, yang mengarah pada efisiensi keunggulan teoritis dibandingkan dengan bensin. Bioetanol dapat dicampur dengan bensin untuk membentuk campuran $(10 \%$ bioetanol dan $90 \%$ bensin), serta dapat digunakan dalam konsentrasi yang lebih tinggi. Bioetanol saat ini dibuat dalam skala besar dengan ragi pada $\mathrm{pH}$ 3,5-5,0 untuk fermentasi gula yang diekstraksi atau dibuat dari tanaman diikuti oleh pemisahan bioetanol dengan distilasi (Balat, dkk., 2008).

Serabut kelapa sawit mempunyai efektifitas yang tidak jauh berbeda dibandingkan dengan batu bara dalam penggunaanya sebagai pembangkit listrik. PLTU dengan asumsi daya 10 MWh membutuhkan 1,3 ton batubara, sementara menggunakan serabut kelapa sawit membutuhkan 1,4 ton (Syafriuddin \& Hanesya, 2012).

Pengukuran nilai kalor dapat menggunakan kalorimeter bomb, Kalorimeter bomb adalah alat yang digunakan untuk mengukur jumlah kalor pada pembakaran sempurna(dalam O2 berlebih) suatu senyawa, bahan makanan, bahan bakar atau khusus digunakan untuk menentukan kalor dari reaksi-reaksi pembakaran (Imam \& Sulistiana, 2011).

Berdasarkan uraian di atas maka diperlukan kajian tentang pemanfaatan lignoselulosa yang terdapat dalam serabut kelapa sawit untuk konversi menjadi bioetanol dan analisis nilai kalornya sebagai bahan bakar tradisional.

\section{Metode \\ Alat dan Bahan}

Peralatan yang digunakan pada penelitian ini adalah neraca analitik, erlenmeyer, gelas kimia, labu ukur, gelas ukur, pipet tetes, corong, penangas listrik, $\mathrm{pH}$ meter, batang pengaduk, aluminium foil, kertas saring, ayakan 40 mesh, magnet stirrer, oven, blender, pompa vakum, seperangkat alat evaporator, alkoholmeter, kalorimeter bomb, stopwatch, ethanol sensor, spektrofotometer UV-VIS T-90.

Bahan yang digunakan yaitu limbah (serabut) kelapa sawit, $\mathrm{H}_{2} \mathrm{SO}_{4} 1 \%$ Aldrich, larutan $\mathrm{HCl} 21 \%$ dan 15\% Aldrich, ammonium sulfat Aldrich, larutan $\mathrm{NaOH}$ Aldrich (2\% dan $6 \mathrm{M})$, urea, ragi tape, anthrone dan aquades.

\section{Prosedur Penelitian \\ Pengukuran Nilai Kalor}

Sampel (serabut kelapa sawit) yang akan diukur nilai kalornya dibuat dalam bentuk pelet dengan berat 1 gram kemudian dilakukan pengukuran kalor dengan kalorimeter bomb pada tekanan 15-20 bar. Setelah melakukan pengukuran tersebut maka nilai kalori dihitung dengan rumus $\mathrm{H}=(\Delta$ T.w.e $) / \mathrm{m}$, dimana $\mathrm{H}$ adalah nilai kalor, $\Delta \mathrm{T}$ adalah suhu konstan, w adalah kalibrasi alat, e adalah faktor koreksi kawat dan $\mathrm{m}$ adalah massa sampel (Imam \& Sulistiana, 2011).

\section{Sintesis bioetanol}

Prosedur kerja yang dikembangkan dalam penelitian ini merupakan hasil modifikasi dari tahap-tahap produksi bioetanol dari biomassa yang telah dilaksanakan oleh (Aryani, dkk., 2013). Beberapa tahap yang dilakukan dalam penelitan ini adalah:

\section{Tahap Pendahuluan}

Pada perlakuan ini limbah kelapa sawit (serabut) diambil di Desa Lalundu Kecamatan Rio Pakava Kabupaten Donggala. Serabut dikukus selama 2 jam kemudian dijemur di bawah sinar matahari selama 1 jam untuk menghilangkan minyaknya. Serabut tersebut dipotong dan ditimbang sebanyak $2 \mathrm{~kg}$. Selanjutnya serabut dicuci dengan air dan dikeringkan dengan bantuan sinar matahari selama 12 jam. Serabut yang sudah kering dipotong dengan ukuran $+1 \mathrm{~cm}$. Setelah itu, serabut digiling dengan blender kemudian diayak dengan menggunakan ayakan 40 mesh. Setelah itu, serabut hasil penggilingan dikeringkan pada suhu $60^{\circ} \mathrm{C}$ selama 4 jam dalam oven. Selanjutnya diayak kembali dengan menggunakan ayakan 40 mesh.

\section{Tahap Delignifikasi}

Pretreatment atau delignifikasi dilakukan dengan mengambil sebanyak $100 \mathrm{~g}$ limbah 
kelapa sawit (serabut) kemudian ditambahkan $1350 \mathrm{~mL}$ aquades dan $150 \mathrm{~mL} \mathrm{NaOH} \mathrm{2 \%}$ ke dalam erlenmeyer. Setelah itu, dipanaskan dan diaduk dengan stirrer selama 2,5 jam pada suhu $80^{\circ} \mathrm{C}$. Larutan dipisahkan dengan cara menyaringnya dengan menggunakan kertas saring. Selanjutnya, residu dioven pada suhu $100^{\circ} \mathrm{C}$ selama 2 jam kemudian menggerusnya hingga halus. Setelah itu, mengayaknya dengan menggunakan ayakan 40 mesh.

\section{Tahap Hidrolisis}

Sebanyak 15 gram limbah kelapa sawit (serabut) ditimbang. Dimana perlakuan tersebut dilakukan sebanyak 18 kali. Setelah itu, limbah kelapa sawit (serabut) dibagi menjadi tiga bagian. Limbah kelapa sawit (serabut) bagian pertama masing-masing ditambahkan dengan larutan $\mathrm{HCl}$ 21\% sebanyak $150 \mathrm{~mL}$. Limbah kelapa sawit (serabut) bagian kedua masingmasing ditambahkan $\mathrm{HCl} 15 \%$ dan limbah kelapa sawit (serabut) bagian ketiga masingmasing ditambahkan $\mathrm{H}_{2} \mathrm{SO}_{4} 1 \%$ sebanyak 150 mL (Sarkar, dkk., 2011). Selanjutnya larutan dipanaskan pada suhu $120^{\circ} \mathrm{C}$ selama 2,5 jam. Kemudian larutan tersebut disaring dengan menggunakan kertas saring. Filtrat yang didapatkan kemudian dianalisis menggunakan spektrofotometer UV-VIS untuk menentukan kadar glukosanya.

\section{Tahap Fermentasi}

Proses fermentasi dilakukan dengan mengambil sebanyak $70 \mathrm{~mL}$ filtrat dan memasukkannya ke dalam erlemeyer. Kemudian filtrate tersebut ditambahkan larutan $\mathrm{NaOH} 6$ $\mathrm{M}$ hingga $\mathrm{pH}$-nya menjadi 5. Masing-masing larutan tersebut ditambahkan dengan 4,2 gram ammonium sulfat dan 4,2 gram urea. Selanjutnya di-pasteurisasi pada suhu $80^{\circ} \mathrm{C}$ selama 15 menit. Kemudian ditambahkan dengan ragi tape sebanyak 4,9 gram. Setelah itu, menutupnya dengan aluminium foil dan dilakukan pendiaman dengan variasi waktu 5 hari dan 11 hari pada suhu $27-30^{\circ} \mathrm{C}$.

\section{Tahap Pemisahan}

Proses evaporasi dilakukan dengan memasukkan hasil fermentasi kedalam erlenmeyer dan dipasang pada rangkaian alat evaporator. Pada proses ini dilakukan pemanasan pada suhu $70^{\circ} \mathrm{C}$. Kemudian masingmasing larutan hasil evaporasi ditentukan kadarnya dengan menggunakan ethanol sensor.

\section{Hasil dan Pembahasan \\ Analisis Kalor}

Hasil analisis kalori dari $0,978 \mathrm{~g}$ sampel serabut kelapa sawit adalah 4708,21 kal/gram. Metode yang digunakan dalam penelitian ini yaitu pengeringan sampel secara manual dibawah paparan sinar matahari selama 12 jam yang kemudian diukur kalornya menggunakan kalorimeter bomb. Metode tersebut sudah sering digunakan dalam penentuan nilai kalor suatu sampel bahan bakar dengan keakuratan yang cukup tinggi. Metode lain yang biasa digunakan yaitu metode fixes carbon. Metode fixed carbon adalah metode karbonisasi, yaitu sampel yang akan diukur dikarbonisasi terlebih dahulu menggunakan reaktor pemanas dengan suhu $500^{\circ} \mathrm{C}$. Nilai kalor suatu sampel cenderung akan meningkat jika dilakukan proses karbonisasi. Sampel limbah serabut kelapa sawit setelah karbonisasi dapat menghasilkan nilai kalor sebesar 6231,22 kal/gram (Syafriuddin \& Hanesya, 2012). Sementara hasil kalor dari serabut kelapa sawit menggunakan metode pengeringan manual selama 12 jam berdasarkan pengujian laboratorium kimia fisik ITB adalah 4875,7857 kal/gram (Sunarwan \& Juhana, 2013). Metode pengeringan digunakan pada penelitian ini untuk mengukur keefektifan limbah serabut kelapa sawit secara ekonomi, nilai kalor menggunakan metode fixed carbon memang lebih tinggi tetapi biaya yang digunakan juga akan lebih besar dan berat sampel yang dihasilkan juga semakin sedikit, sementara dalam penelitian ini diharapkan untuk menghasilkan bahan bakar yang ekonomis dan ramah lingkungan.

Joule dalam Syafriuddin \& Hanesya (2012) melakukan konversi satuan energi dari MWh ke Joule. Sebagai perbandingan analisa ini diasumsikan bahwa generator PLTU menghasilkan daya sebesar $10 \mathrm{MWh}$. Sesuai dengan parameter konversi satuan energi yang menyatakan $1 \mathrm{MWh}=3.600 .000$ kilojoule, sehingga $10 \mathrm{MWh}=36.000 .000$ kilojoule.

Hasil pengujian nilai kalor serabut kelapa sawit sebesar 4708,21 kal/gram, apabila nilai kalor tersebut dikonversikan maka didapat nilai sebagai berikut: $4708.21 \mathrm{kkal} / \mathrm{kg}$, dimana $1 \mathrm{kal}=4,2 \mathrm{~J}$ dan $1 \mathrm{kkal}=4,2 \mathrm{~kJ}$. Dengan nilai tersebut maka kuantitas limbah serabut kelapa sawit sebesar: $1820,582 \mathrm{~kg}(1,8$ ton).

\section{Sintesis Bioetanol}

Serabut kelapa sawit mengandung karbohidrat sebesar $38,80 \%$ dan lignin sebesar 26\% (Syafriuddin \& Hanesya, 2012). Proses delignifikasi atau degradasi lignin harus 
dilakukan terlebih dahulu untuk mengisolasi karbohidrat. Proses ini penting dilakukan sebab lignin merupakan dinding kokoh yang melekat pada serat selulosa dan hemiselulosa sehingga suatu tanaman menjadi keras dan dapat berdirikokoh. Adanya lignin ini dapat menghambat penetrasi asam sebelum hidrolisis berlangsung dan menghambat pertumbuhan mikroba dalam proses fermentasi. $\mathrm{NaOH}$ digunakan untuk melakukan delignifikasi, fungsi antara lain yaitu untuk dapat merusak lignin bagian amorf dan kristalin, melarutkan lignin dan hemiselulosa dan mengembangkan struktur selulosa (Aryani, dkk., 2013). Proses delignifikasi ini menyebabkan perubahan warna larutan menjadi coklat dari sebelumnya yang berwarna bening.

Substrat serabut kelapa sawit hasil delignnifikasi kemudian dihidrolisis menggunakan asam kuat, dalam studi ini digunakan $\mathrm{H}_{2} \mathrm{SO}_{4}$ dan $\mathrm{HCl}$ dengan variasi konsentrasi. $\mathrm{H}_{2} \mathrm{SO}_{4}$ dengan konsentrasi $1 \%$ dan $\mathrm{HCl}$ konsentrasi $15 \%$ dan 21\%. Proses hidrolisis dengan asam terdiri dari dua tipe, yaitu asam encer dan asam pekat. Hidrolisis dengan asam biasanya menggunakan asam sulfat, asam fospat, asam asam nitrat dan asam klorida. Hidrolisis dengan asam encer akan lebih baik jika menggunakan asam sulfat untuk bahan yang mengandung lignoselulosa dari berbagai jenis biomassa (Balat, dkk., 2008). Hidrolisis ini bertujuan untuk mengubah selulosa menjadi glukosa.Setelah dilakukan hidrolisis selama $2.5 \mathrm{jam}$, pada suhu $100^{\circ} \mathrm{C}$ sampel mengalami perubahan warna sebagai mana tertera dalam Tabel 1 .

Tabel 1 Perubahan warna larutan setelah hidro-

\begin{tabular}{|cc|}
\multicolumn{2}{c}{ lisis } \\
\hline Konsentrasi asam & Warna \\
\hline $\mathrm{H}_{2} \mathrm{SO}_{4} 1 \%$ & Coklat muda \\
$\mathrm{HCl} 15 \%$ & Coklat \\
$\mathrm{HCl} 21 \%$ & Coklat tua \\
\hline
\end{tabular}

Perubahan warna ini menandakan terjadinya perubahan senyawa selulosa menjadi glukosa, adapun perbedaan warna yang dihasilkan disebabkan oleh perbedaan kekuatan hidolisis dari masing-masing asam. Tabel 1 menunjukkan pembentukan glukosa hasil hidrolisis maksimum pada $\mathrm{HCl} 15 \%$ yang ditandai dengan warna filtrat berwarna coklat. $\mathrm{H}_{2} \mathrm{SO}_{4} \quad 1 \%$ menghasilkan warna coklat muda, hal ini disebabkan belum terjadi degradasi sempurna hemiselulosa maupun selulosa menjadi glukosa, sedangkan $\mathrm{HCl} 21 \%$ menghasilkan filtrat berwarna coklat tua, hal ini disebabkan degradasi lanjut hemiselulosa dan selulosa menjadi karbon. Perubahan warna dalam reaksi ini sesuai dengan penjelasan yang yang telah disampaikan pada penelitian sebelumnya (Aryani, dkk., 2013)

Kadar glukosa dari filtrat hasil hidrolisis diukur dengan menggunakan metode anthrone. Metode anthrone adalah salah satu metode yang digunakan untuk menentukan kadar gula pereduksi dengan menggunakan pereaksi anthrone (Apriyantono, dkk., 1989). Pengukuran kadar glukosa ini dilakukan untuk mengetahui asam yang paling baik digunakan dalam proses hidrolisis. Pembuatan kurva standar dilakukan dengan melarutkan glukosa standar dalam aquades. Selain itu juga dibuat larutan blanko dari aquades. Masing-masing larutan diaambil $1 \mathrm{~mL}$ kemudian ditambahkan $5 \mathrm{~mL}$ pereaksi anthrone. Selanjutnya larutan dipanaskan selama 12 menit, setelah itu larutan didinginkan pada gelas piala yang berisi air dan kemudian diukur absorbansinya pada panjang gelombang $630 \mathrm{~nm}$ (Apriyantono, dkk., 1989). Hasil pengukuran kadar glukosa (ppm) menggunakan metode anthrone dapat dilihat dalam Tabel 2.

Tabel 2. Perubahan warna larutan setelah hi-

\begin{tabular}{|cc}
\multicolumn{2}{c}{ drolisis } \\
\hline Konsentrasi asam & Warna \\
\hline $\mathrm{H}_{2} \mathrm{SO}_{4} 1 \%$ & Coklat muda \\
$\mathrm{HCl}^{1} 15 \%$ & Coklat \\
$\mathrm{HCl} 21 \%$ & Coklat tua \\
\hline
\end{tabular}

Tabel 2 menunjukkan kadar glukosa terbanyak hasil hidrolisis dicapai pada konsentrasi $\mathrm{HCl} 15 \%$ dengan konsentrasi 94000,169 ppm. Dalam proses hidrolisis gugus $\mathrm{H}^{+}$dari $\mathrm{HCl}$ akan membentuk radikal bebas dari serbut kelapa sawit yang kemudian akan bereaksi dengan gugus $\mathrm{OH}$ - dari air dan menghasilkan glukosa (Aryani, dkk., 2013). $\mathrm{H}_{2} \mathrm{SO}_{4} 1 \%$ mempunyai jumlah $\mathrm{H}^{+}$yang belum mencukupi yang membuat tidak banyak radikal bebas yang terbentuk sehingga glukosa yang dihasilkan belum maksimal. Penambahan asam dalam konsentrasi yang terlalu besar menyebabkan jumlah air semakin menurun sehingga glukosa yang akan dihasilkanpun juga 
sedikit, hal itulah yang terjadi pada $\mathrm{HCl} 21 \%$. Asam penghidrolisis yang maksimum pada percobaan ini yaitu $\mathrm{HCl} \mathrm{15 \% .} \mathrm{Mekanisme}$ hidrolisis selulosa dapat dilihat pada Gambar 1.

Filtrat hasil hidrolisis menggunakan
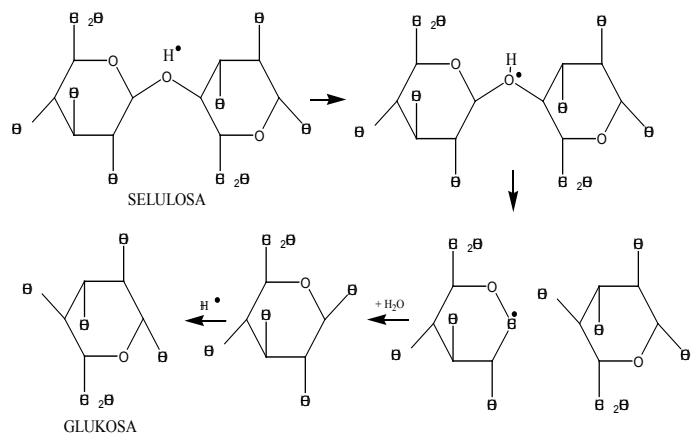

Gambar 1. Mekanisme Hidrolisis Selulosa

$\mathrm{HCl} \quad 15 \%$ difermentasi menggunakan Saccharomyces cerevisiae ditambah bahan pendukung urea dan ammonium sulfat, bahan tersebut berfungsi sebagai nutrisi dalam proses fermentasi. Mikroba saccharomyces cerevisiae dapat mengkorversi gula menjadi etanol karena adanya enzim invertase dan enzim zimase yang dihasilkan oleh mikroba tersebut. Dengan adanya kedua enzim tersebut mikroba saccharomyces cerevisiae memiliki kemampuan untuk mengkonversi gula dari kelompok monosakarida maupun dari kelompok disakarida. Jika gula di dalam substrat adalah kelompok disakarida maka enzim invertase akan menghidrolisis disakarida menjadi monosakarida. Setelah itu, enzim zimase akan mengkonversi monosakarida tersebut menjadi alkohol dan karbondioksida (Judoamidjojo, dkk., 1992). Selanjutnya campuran diinkubasi dengan cara memanaskan larutan dalam penangas air untuk menambah daya simpan larutan. Selanjutnya larutan difermentasi Selama 5 hari dan 11 hari untuk menghasilkan etanol. Hasil fermentasi didestilasi pada suhu 70 oC untuk memisahkan etanol dari larutan. Hasil fermentasi di uji menggunakan etanol sensor. Analisis terhadap kadar etanol (\%) hasil fermentasi ditunjukkan pada Gambar 2.

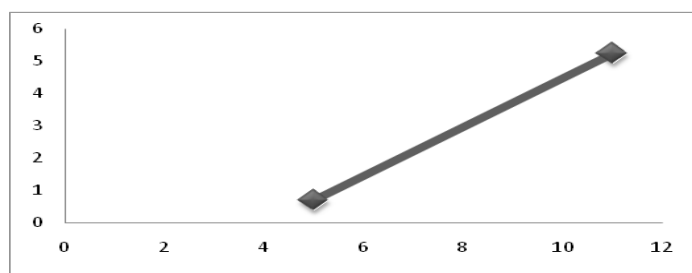

Gambar 2. Grafik hubungan lama fermentasi dengan kadar etanol (\%)
Gambar 4 menunjukkan bahwa semakin lama waktu fermentasi maka kadar etanol yang dihasilkan juga semakin tinggi. Hal ini disebabkan oleh pertumbuhan mikroba yang semakin cepat sehingga menghasilkan etanol yang lebih banyak. Penelitian ini belum mendapatkan titik optimumnya, fermentasi yang melebihi 11 hari dapat saja terus mengalami peningkatan kadar etanol tapi bisa sebaliknya hal ini karena pada fermentasi lanjut etanol bisa mengalami perubahan menjadi asam karbosilat ataupun ester (Sari, dkk., 2008).

\section{Efektifitas Serabut kelapa sawit sebagai alternatif bahan bakar terbarukan}

Serabut kelapa sawit dapat digunakan sebagai alternatif bahan bakar terbarukan baik secara tradisional maupun modern. Nilai kalor serabut kelapa sebagai bahan bakar tradisional yaitu sebesar $911266,4 \mathrm{~kJ} / \mathrm{mol}$ atau setara dengan 4708,21 kal/g, sementara sebagai bahan bakar modern (bioetanol) yaitu sebesar $1364 \mathrm{~kJ} / \mathrm{mol}$. Bahan bakar dari serabut kelapa sawit baik secara tradisional maupun modern mempunyai dampak lingkungan yang kecil, tetapi dari segi ekonomi maupun nilai kalori, pemanfaatan serabut kelapa sawit sebagai bahan bakar tradisional mempunyai efektifitas yang lebih besar jika digunakan sebagai bahan bakar modern (bioetanol). PLTU dengan asumsi daya sebesar $10 \mathrm{MWh}$ membutuhkan batu bara sebesar 1,3 ton sementara dengan menggunakan serabut kelapa sawit sebesar 1,8 ton, tetapi batubara mempunyai dampak lingkungan yang besar dan biaya yang lebih mahal jika dibandingkan dengan menggunakan serabut kelapa sawit (Syafriuddin \& Hanesya, 2012)

\section{Kesimpulan}

Nilai kalor dari serabut kelapa sawit sebesar $4708,21 \mathrm{kal} / \mathrm{gram}$. Kadar etanol tertinggi hasil fermentasi dari serabut kelapa sawit diperoleh dalam prosess selama 11 hari yaitu sebesar $5,23 \%$ dengan hidrolisis menggunakan $\mathrm{HCl}$ $15 \%$.

\section{Ucapan Terima Kasih}

Ucapan terima kasih penulis berikan kepada laboran Laboratorium Agroteknologi FAPERTA Universitas Tadulako yang banyak membantu penulis dalam menyelesaikan penelitian ini.

\section{Referensi}

Akhmad, S. U., Sapta, R., \& Novia. (2012). Pengaruh volume enzim dan waktu 
fermentasi terhadap kadar etanol (bahan baku tandan kosong kelapa sawit dengan pretreatment alkali). Jurnal Teknik Kimia, 18(2), 17-25.

Alvira, E., Pejo, T., Ballesteros, M., \& Negro, M. J. (2009). Pretreatment technologies for an efficient bioethanol production process based on enzymatic hydrolysis: A review. Journal Bioresource Technology, 101(13), 4851-4861.

Apriyantono, A., Fardiaz, N. L., Puspitasari, Sedernawati, \& Budiyanto. (1989). Petunjuk laboratorium analisis pangan. Bogor: Departemen Direktorat Jenderal Tinggi Pusat Antar Universitas Pangan dan Gizi-IPB.

Aryani, E., Kusumo, E., \& Supartono. (2013). Produksi bioetanol dari jerami padi (oryza sativa L). Jurnal Institut Teknologi Nasional, 2(2), 168-172.

Balat, M. (2011). Production of bioethanol from lignocellulosic materials via the biochemicalpathway: A review. Journal Energy Convertion and Management, 52, 858-875.

Balat, M., Balat, H., \& Oz, C. (2008). Progress in bioethanol processing. Journal Progress in Energy and Combustion Science, 34, 551-573.

Haryono, Kurniawan, R., Nurhayati, A., \& Soviyani, D. A. (2010). Pembuatan bioetanol dari bahan berbasis selulosa. Jurnal Institut Teknologi Nasional, 2(4), $1-7$.

Imam, T., \& Sulistiana. (2011). Uji kalor bahan bakar campuran bioetanol dan minyak goreng bekas. Jurnal Neutrino, 3(2), 163174.

Jannah, A. M. (2010). Proses fermentasi hidrolisa jerami padi untuk menghasilkan bioetanol. Teknik Kimia, 17(1), 44-52.

Judoamidjojo, M., Darwis, A. A., \& Sa'id, E. G. (1992). Teknologi fermentasi. Jakarta: Rajawali Press.

Sari, I. M., Noverita, \& Yulneriwarni. (2008). Pemanfaatan jerami padi dan alang-alang dalam fermentasi etanol menggunakan kapang trichoderma viride dan kamir saccharomycess cerevisiae. Jurnal Vis Vitalis, 5(2), 55-62.

Sarkar, N., Ghosh, S. K., Bannerjee, S., \& Aikat, K. (2011). Bioethanol production from agricultural wastes: An overview. Jurnal Renewable Energy, 37(2012), 19-27.

Sumada, K., Tamara, P. E., \& Alqani, F. (2011). Kajian proses isolasi $\alpha$-selulosa dari limbah batang tanaman manihot esculenta crantz yang efisien. Jurnal Teknik Kimia, 5(2), 434-438.

Sunarwan, B., \& Juhana, R. (2013). Pemanfaatan limbah sawit untuk bahan bakar energi baru dan terbarukan (Ebt). Jurnal Tekno Intensif Kopwil 4, 7(2), 1-14.

Syafriuddin, \& Hanesya, R. (2012). Perbandingan penggunaan energi alternatif bahan bakar serabut (fiber) dan cangkang kelapa sawit terhadap bahan bakar batubara dan solar pada pembangkit listrik. Jurnal Prosiding Seminar Nasional Aplikasi Sains \& Teknologi (SNAST) Periode III, 2, 162170 . 